\title{
PRODUCT INNOVATION PROCESS: A MODEL BASED ON MANUFACTURING READINESS LEVEL (MRL), DESIGN FOR MANUFACTURING AND ASSEMBLY (DFMA) AND TECHNOLOGY READINESS LEVEL (TRL)
}

Cristiano Vasconcellos Ferreira (cristiano.v.ferreira@ ufsc.br) - Universidade Federal de Santa Catarina, UFSC

Fernando Luiz Biesek (fernando.biesek@embraco.com) - Embraco

Regis Kovacs Scalice (regis.scalice@ ufsc.br) - Universidade Federal de Santa Catarina, UFSC

\begin{abstract}
The product development process is important for industrial competitiveness. Many companies have been reorganizing from a sequential to an integrated path known as simultaneous engineering, whose objective is to reduce development time and costs. This paper proposes a model to improve the use of simultaneous engineering by integrating project and manufacturing knowledge areas based on concepts of Manufacturing Readiness Level, Design for Manufacturing and Assembly and Technology Readiness Level. Based on a bibliographic review and a preliminary study conducted over one year in a multinational metalworking company, a model was proposed that is a systematic approach composed of a sequence of activities and tools to be applied in the early stages of product development. To evaluate this model, a workshop involving professionals who work in the product development was held. The results show an integration of proposed engineering areas into a product development process, reflected by a product cost reduction of $20 \%$ and manufacturing investments of $25 \%$, which are mainly related to a $33 \%$ reduction in number of parts and to changes in the concepts of joints and in the component manufacturing process. The effectiveness of the model was also proven as a working tool and a reference model.
\end{abstract}

Key words:: MRL, DFMA, TRL, Product Innovation 


\section{INTRODUCTION}

The product development process (PDP) is complex for its multidisciplinary knowledge (KARNIEL; REICH, 2011). A structured PDP is essential for an industry's competitiveness and survival, and is composed by multifunctional activities influenced by many internal and external factors (HADDAD et al., 2012).

Alves (2009 apud Araújo, 2017) creates a category of innovation named precompetitive technological innovation, where a company's domain for certain technologies, which can be adopted in the development of new products, is sought. In this context, the technology maturity evaluation matters, because low-maturity projects need time to mature.

To evaluate the maturity of new technologies, the National Aeronautics and Space Administration (NASA) introduced a scale called the Technology Readiness Level (TRL) (MANKINS, 2009). In addition, the US Department of Defense (DoD) has a Manufacturing Readiness Level (MRL) scale to measure the maturity of manufacturing technologies similarly to the OSD Manufacturing Technology Program, (2011).

In that scenario, in this paper is propose a systematic model for the integration of design and manufacturing during the development stage of technology products, through the use of MRL, TRL and DFMA.

\section{PRODUCT DEVELOPMENT PROCESS AND INNOVATION}

For this work, the models used as reference and theoretical basis are the traditional Stage-Gate of Cooper (1994) and the Technological Stage-Gate (TSG) proposed by Marxt et al. (2004). The Stage-Gate is characterized by the procedural form that materializes the knowledge along the proposed stages. This model is organized as a list of predetermined stages called gates, which control the processes and serve as evaluation points, as follows: a) Selection of ideas; b) Research and Development; c) Implementation and d) Introduction to the Market. Technology Stage-Gates (TSG) include the stages of technology development. Such phases are introduced during product idea. These TSG can start in the Research and Development phase of the Cooper model (1994), going all the way to the end of the product's life cycle. In the TSG, there are Technical Reviews, which are formalized in a Technical Review Committee. The main purpose of such reviews is to ensure the scope of a project throughout the product's life cycle. 
Like so, the phases of Research and Development (R\&D) can be associated to the phases of traditional product development. The main use of the TSG is in projects whose technologies are still in development, with high levels of uncertainty as to the real market potential, that is, in typical cases of $R \& D$ projects.

\section{TECHNOLOGY READINESS LEVEL (TRL) AND MANUFACTURING READINESS LEVEL (MRL)}

To support project development from the research phases, two technology-maturity measurement scales are presented for both the product that is being created and the manufacturing processes. Such scales are called Technology Readiness Level (TRL) and Manufacturing Readiness Level (MRL).

NASA's technology maturity scale has 9 levels described as: TRL 1- Basic principles observed and reported, TRL 2- Technology concept or application formulated, TRL 3- Experimental and/or analytical proof-of-concept for critical function and characteristics, TRL 4- Component or breadboard validation in a laboratory environment, TRL 5- Component or breadboard validation in a relevant environment, TRL 6- System or subsystem model or prototype demonstrated in a relevant environment, TRL 7- System prototype demonstration in an operational environment, TRL 8- Actual system completed and "flight qualified" through test and demonstration and TRL 9- Actual system "flight proven" through successful mission operations.

The MRL, as initially referred to in the OSD Manufacturing Technology Program (2011), was developed by the US Department of Defense (DoD), whose idea was to create a scale to serve manufacturing the same purpose that TRL served technology, so there would be a common vocabulary, and evaluations of manufacturing maturity levels could be made into projects.

Figure 01 shows the acquisition life cycle proposed in the Manufacturing Readiness Level Deskbook (2016) and its relation to the TRL scale. Three milestones are condensed in the model, represented by A, B and C.

Milestone A aims to validate the ability to produce the technology in a laboratory environment, $\mathrm{B}$ validates the ability to produce the product in a relevant production environment, and $\mathrm{C}$ validates the ability to produce the product on a pilot line. 


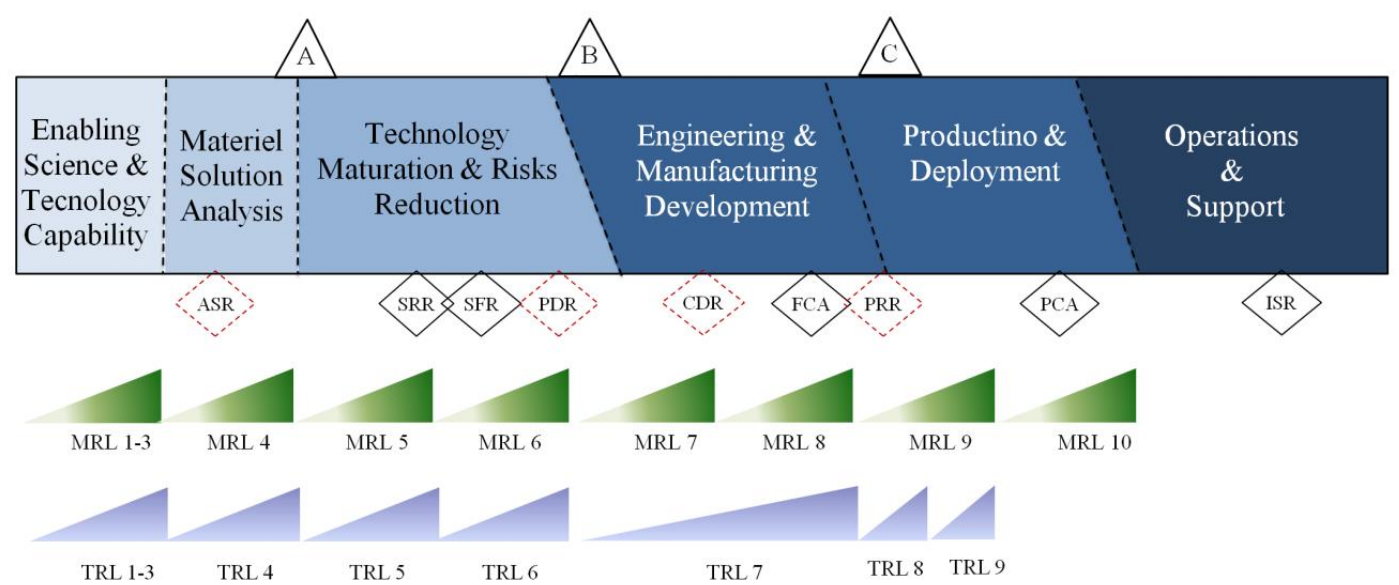

FIGURE 1 - DoD Acquisition lifecycle (Source: Manufacturing Readiness Level Deskbook, 2016).

In order to avoid budget delays or disparities, Mankins (2009) proposed a matrix evaluation model called Technology Readiness and Risk Assessment (TRRA) that would help project managers make technology maturity clear and documented in the initial stages of the project. For both Pf and Cf, 5 levels were created regarding the probability and consequence of failures that should be related to the risk matrix (TRRA) in Figure 02.

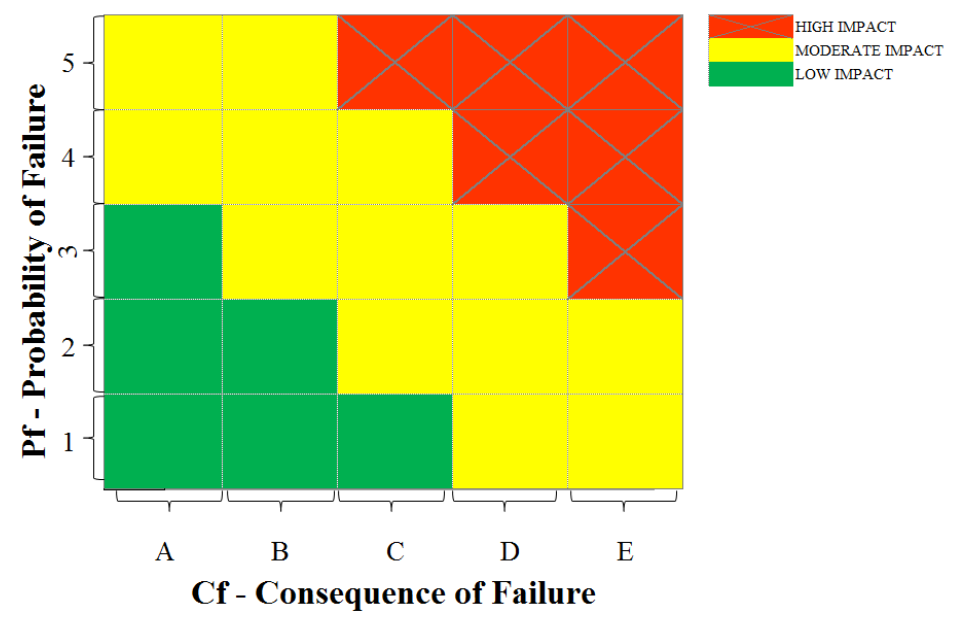

FIGURE 2 - Matrix of technological risks (TRRA) (Source: Mankins, 2009)

\section{DESIGN FOR MANUFACTURING AND ASSEMBLY (DFMA)}

The term Design for Manufacturing refers to the design for easy manufacturing of parts that form the product after assembly, while Design for Assembly is related to product design for easy assembly. Design for Manufacturing and Assembly (DFMA) is a combination of DFA and DFM, (BOOTHROYD; DEWURST; KNIGHT, 2011). 
There are several DFMA methods or techniques for concurrent engineering development. The three best known are the Boothroyd-Dewurst DFMA method, the Hitachi Assemblability Evaluation Method and the Lucas Technique (EHRS, 2012)

The Lucas DFA method was developed by the University of Hull and has the same research base as Boothroyd-Dewhurst (2011), so they present some common characteristics, which are the reduction of the number of pieces and the analysis of the pieces' geometry to the assembly process (ESQUILANDER, 2001).

The Boothroyd-Dewurst method tends to require more information about the product, such as processing and assembly times. The Lucas method is based on standardized and tabulated parameters, which allows for greater flexibility in input data and even in evaluation.

\section{PRODUCT INNOVATION PROCESS MODEL}

The systematic proposed to improve the integration between the design and manufacturing areas in pre-competitive technological research and development is composed of the following phases: Technology Development, Solutions Analysis and Advanced Technological Development. Figure 3 presents the structure.

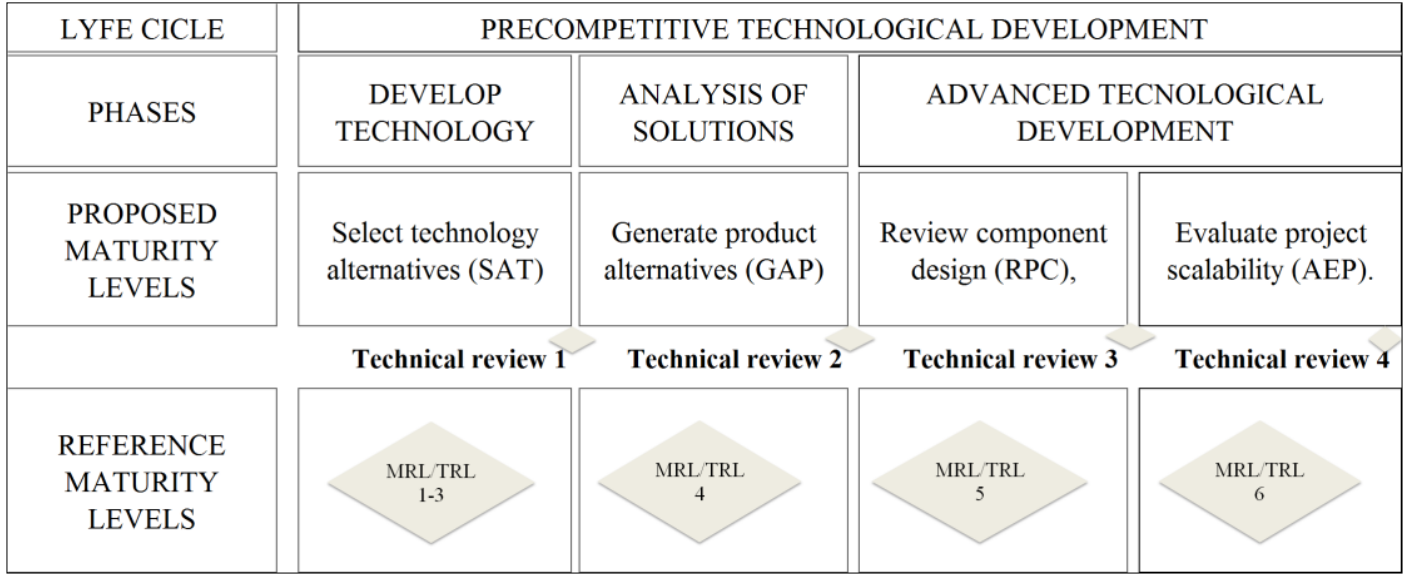

FIGURE 3 - Proposed model framework (Source: author, 2017)

In the presented model, those phases are associated with technology maturity levels: Selecting alternative technology (SAT), generating alternative product (GAP), reviewing component design (CDR), and evaluating project scalability (PSE). These steps are, in turn, correlated to the levels of TRL and MRL 
Thus, in the end of the proposed method, we have a product and manufacturing project ready to enter the development phase with the following characteristics: (1) product features such as dimensions, critical dimensions and defined materials, (2) product design maturity evaluation from the DFMA point of view, (3) investments and costs updated with a high level of assertiveness, which will enable a good feasibility analysis and (4) risk analysis to aid in decision making and definitions on the next steps.

The proposition is organized in four large blocks, which are presented on table 1.

TABLE 1 - Model integration guide.

\begin{tabular}{|c|c|c|c|c|}
\hline $\begin{array}{c}\text { Maturity } \\
\text { level }\end{array}$ & In puts & Steps & Out puts & Generated Document \\
\hline \multirow{2}{*}{ 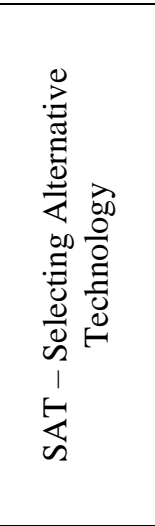 } & $\begin{array}{l}\text { 1.Market } \\
\text { problem } \\
\text { 2.Technolog } \\
\text { y list }\end{array}$ & $\begin{array}{l}\text { 1. Identify technology } \\
\text { gaps and classify them. }\end{array}$ & $\begin{array}{l}\text { 1.Technology opportunity } \\
\text { gaps identified } \\
\text { 2.Critical technologies list } \\
\text { regarding manufacture and } \\
\text { product created } \\
\text { 3. Potential benefits } \\
\text { 4.Maturity levels classified } \\
\text { (MLR) and (TRL) }\end{array}$ & $\begin{array}{l}\text { 1. Technology Road Map. } \\
\text { 2. Classification table of } \\
\text { technologies. } \\
\text { 3. Expert Opinion } \\
\text { 4. Lessons Learned } \\
\text { 5. TRL Assessment } \\
\text { 6. MRL Assessment } \\
\text { 7. Risk Matrix filled } \\
\end{array}$ \\
\hline & $\begin{array}{l}\text { SAT step } 1 \\
\text { out puts } 1,2 \text {, } \\
3 \text { and } 4 .\end{array}$ & $\begin{array}{l}\text { 2. Proven new } \\
\text { technology concepts }\end{array}$ & $\begin{array}{c}\text { 1. Technology Feasibility } \\
\text { tests } \\
\text { 2.Development gaps } \\
\text { 3.Cost variation, } \\
\text { Investment and risks }\end{array}$ & $\begin{array}{l}\text { 1.MRL Check list } \\
\text { 2.Risk matrix filled }\end{array}$ \\
\hline 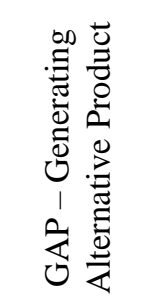 & $\begin{array}{l}\text { SAT step } 1 \\
\text { and step } 2 \\
\text { out puts }\end{array}$ & $\begin{array}{l}\text { 3. Generate conceptual } \\
\text { product model and } \\
\text { define its sub functions } \\
\text { 4. Evaluate product } \\
\text { concept under DFMA } \\
\text { point of view }\end{array}$ & $\begin{array}{l}\text { 1.Product model design } \\
\text { with dimensions and } \\
\text { preliminary specifications } \\
\text { 2.Design maturity } \\
\text { evaluation - DFMA } \\
\text { 3.Cost variation, } \\
\text { Investment and risks }\end{array}$ & $\begin{array}{c}\text { 1.DFA Matrix } \\
\text { 2.DFM Matrix } \\
\text { 3.DFMA Matrix } \\
\text { 4.Risk matrix filled } \\
\text { 5.Specialist analysis }\end{array}$ \\
\hline 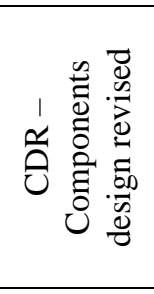 & $\begin{array}{l}\text { GAP step } 3 \\
\text { and step } 4 \\
\text { out puts }\end{array}$ & $\begin{array}{l}\text { 5. Optimize product } \\
\text { design under DFMA } \\
\text { and automation view. } \\
\text { 6.Produce components } \\
\text { in prototype tooling } \\
\text { 7.Assemble product in } \\
\text { laboratory }\end{array}$ & $\begin{array}{l}\text { 1. Basic product model } \\
\text { design review with } \\
\text { optimized components } \\
\text { 2.DFMA indexes reviewed } \\
\text { 3.Cost variation, } \\
\text { Investment and risks } \\
\text { review }\end{array}$ & $\begin{array}{l}\text { 1.DFA Matrix review } \\
\text { 2.DFM Matrix review } \\
\text { 3.DFMA Matrix review } \\
\text { 4.Risk matrix review } \\
\text { 5.Design for automation } \\
\text { rules }\end{array}$ \\
\hline 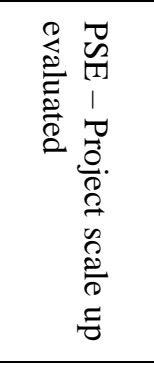 & $\begin{array}{l}\text { CDR step } 5 \text {, } \\
6 \text { and } 7 \text { out } \\
\text { puts }\end{array}$ & $\begin{array}{l}\text { 8. Assemble product in } \\
\text { a advanced } \\
\text { manufacturing } \\
\text { laboratory to approve } \\
\text { tooling and technology. } \\
\text { 9.Review product } \\
\text { analysis based on } \\
\text { DFMA rules }\end{array}$ & $\begin{array}{l}\text { 1. Product model design } \\
\text { review with critical } \\
\text { dimension and materials } \\
\text { defined } \\
\text { 2.Product DFMA } \\
\text { evaluation reviewed } \\
\text { 3.Cost variation, } \\
\text { Investment and risks } \\
\text { reviewed } \\
\end{array}$ & $\begin{array}{l}\text { 1.DFA Matrix review } \\
\text { 2.DFM Matrix review } \\
\text { 3.DFMA Matrix review } \\
\text { 4.Risk matrix review }\end{array}$ \\
\hline
\end{tabular}


A technical review meeting should be held at the end of each phase, involving a multifunctional team from the design and manufacturing areas. At this moment, the project team must check the generated documents to evaluate if the project is ready to go to the next phase. The main documents that must be used in such evaluation are: a MRL check list in SAT level, DFA, DFM, DFMA and Risk Matrixes for all maturity levels.

\section{PRELIMINARY CASE STUDY.}

A preliminary case study was performed during the technological development of a new subsystem of a product, called project $X$. The objective was to validate the application of three matrices, the DFA, the DFM and the DFMA, already presented in table 1, as a generated document. Those matrices are the main communication tool for the process.

To understand Project X's level of maturity then, a correlation was made between the stage definitions proposed in the MRL scale with the maturity stage definitions of the Enterprise Product Development Process R, and the remaining maturity stages defined by MRL2, MRL3 and MRL4.

To apply the model, the matrix proposed in Figure 4 was used in step 1, adapted from Stienstra (2016) example, where the components are evaluated in relation to the DFA criteria using the symbols Y (Yes) and N (No). In this matrix, the maturity evaluation is performed based on project guidelines and penalty factors, proposed by Lucas (1993)'s methodology, which are used to calculate the assemblability indices, called measures of performance (MOP) (SQUILANDER, 2001).

The DFA evaluation matrix has 3 main fields, identified in Figure 4 as A, B and C, where field A presents the general and partial project guidelines based on the DFA, aligned with the Stienstra (2016) and Lucas (1993) criteria. There are 6 general guidelines presented as topics at Level N1. The partial guidelines are 21 and topics or questions are presented in N2.

In field B, the product's components are described, evaluated and compared with the N2 level rules. The components are organized into subsets (SB01, SB02, ...).

Field $\mathrm{C}$ shows the evaluation responses, which are the numerical indices calculated based on the general and partial guidelines. N5 is meant to transfor the answers $\mathrm{Y}$ and $\mathrm{N}$ into numbers using equations 9 and 10. Equation 9 only points out the number of $\mathrm{Y}$ responses and is valid 
for columns from (a) to (f). Equation 10 points out the number of $\mathrm{Y}$ or $\mathrm{N}$ responses and multiplies them by the penalty factors related to the DFMA guideline level 2 (N2) proposed by (LUCAS, 1993)'s method of calculation. Equation 2 is valid for columns (g) through (u). These values are the numerical basis for calculating the indicators at levels N6 and N7.

\begin{tabular}{|c|c|c|c|c|c|c|c|c|c|c|c|c|c|c|c|c|c|c|c|c|c|c|c|}
\hline \multicolumn{24}{|c|}{ DFA MATRIX } \\
\hline \multicolumn{2}{|c|}{ Section Levels } & \multicolumn{22}{|c|}{ Evaluation Aspects } \\
\hline \multirow{3}{*}{ A } & $\mathrm{N} 1 \rightarrow$ & General Guidelines & \multicolumn{2}{|c|}{$\begin{array}{c}\text { 1.DFA general } \\
\text { index }\end{array}$} & \multicolumn{2}{|c|}{$\begin{array}{l}\text { 2. BOM } \\
\text { Costs }\end{array}$} & \multicolumn{2}{|c|}{ 3.Quality } & \multicolumn{7}{|c|}{ 4. Handling } & \multicolumn{7}{|c|}{ Standard Junctions and Unions } & \multirow{2}{*}{$\begin{array}{l}\text { Other } \\
\text { Unions }\end{array}$} \\
\hline & $\mathrm{N} 2 \rightarrow$ & Partial or Specific Guidelines & 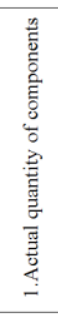 & 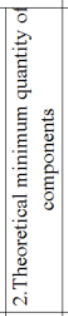 & 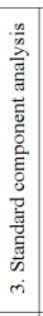 & 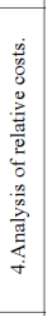 & 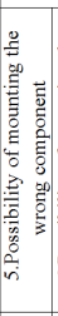 & 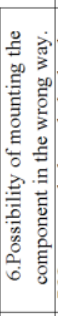 & 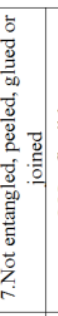 & 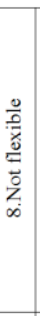 & 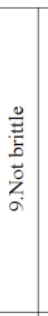 & 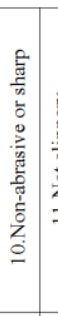 & 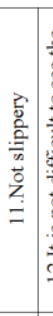 & 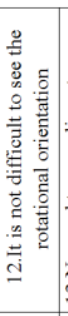 & 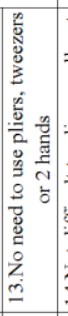 & 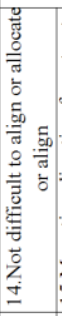 & 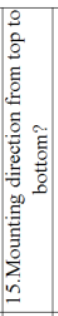 & 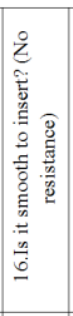 & 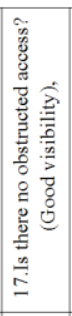 & 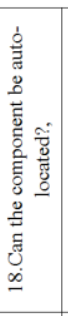 & 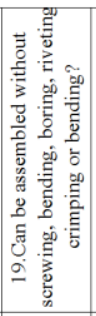 & 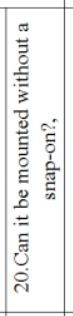 & \\
\hline & N3 $\rightarrow$ & Penalty Factors & - & - & - & - & - & - & - & - & - & - & - & - & - & - & - & - & - & - & - & - & - \\
\hline \multirow{8}{*}{ B } & \multirow{8}{*}{$\mathrm{N} 4 \rightarrow$} & SB 01 & & & & & & & & & & & & & & & & & & & & & \\
\hline & & Component A & $\mathrm{x}$ & $\mathrm{N}$ & $\mathrm{Y}$ & $\mathrm{N}$ & Y & $\mathrm{Y}$ & Y & $\mathrm{Y}$ & Y & Y & $\mathrm{Y}$ & Y & Y & Y & $\mathrm{Y}$ & Y & $\mathrm{Y}$ & $\mathrm{N}$ & $\mathrm{N}$ & $\mathrm{N}$ & $\mathrm{N}$ \\
\hline & & Component B & Y & $\mathrm{N}$ & $\mathrm{N}$ & $\mathrm{N}$ & $\mathrm{N}$ & $\mathrm{N}$ & $\mathrm{N}$ & $\mathrm{N}$ & $\mathrm{N}$ & $\mathrm{N}$ & $\mathrm{N}$ & $\mathrm{N}$ & $\mathrm{N}$ & $\mathrm{N}$ & $\mathrm{Y}$ & $\mathrm{N}$ & $\mathrm{N}$ & $\mathrm{N}$ & $\mathrm{N}$ & $\mathrm{N}$ & $\mathrm{N}$ \\
\hline & & \begin{tabular}{|l} 
Component $\mathrm{n}$ \\
\end{tabular} & $z$ & $\mathrm{~N}$ & $\mathrm{~N}$ & $\mathrm{~N}$ & $\mathrm{~N}$ & $\mathrm{~N}$ & $\mathrm{~N}$ & $\mathrm{~N}$ & $\mathrm{~N}$ & $\mathrm{~N}$ & $\mathrm{~N}$ & $\mathrm{~N}$ & $\mathrm{~N}$ & $\mathrm{~N}$ & $\mathrm{Y}$ & $\mathrm{N}$ & $\mathrm{N}$ & $\mathrm{N}$ & $\mathrm{N}$ & $\mathrm{N}$ & $\mathrm{N}$ \\
\hline & & SB n & & & & & & & & & & & & & & & & & & & & & \\
\hline & & Component A & $\mathrm{x}$ & $\mathrm{N}$ & $\mathrm{Y}$ & $\mathrm{N}$ & $Y$ & $\mathrm{Y}$ & $Y$ & Y & $\mathrm{Y}$ & $\mathrm{Y}$ & $Y$ & Y & $Y$ & $\mathrm{Y}$ & Y & $\mathrm{Y}$ & $\mathrm{Y}$ & $\mathrm{N}$ & $\mathrm{N}$ & $\mathrm{N}$ & $\mathrm{N}$ \\
\hline & & Component B & $\mathrm{Y}$ & $\mathrm{N}$ & $\mathrm{N}$ & $\mathrm{N}$ & $\mathrm{N}$ & $\mathrm{N}$ & $\mathrm{N}$ & $\mathrm{N}$ & $\mathrm{N}$ & $\mathrm{N}$ & $\mathrm{N}$ & $\mathrm{N}$ & $\mathrm{N}$ & $\mathrm{N}$ & $\mathrm{Y}$ & $\mathrm{N}$ & $\mathrm{N}$ & $\mathrm{N}$ & $\mathrm{N}$ & $\mathrm{N}$ & $\mathrm{N}$ \\
\hline & & Component $\mathrm{n}$ & $z$ & $\mathrm{~N}$ & $\mathrm{~N}$ & $\mathrm{~N}$ & $\mathrm{~N}$ & $\mathrm{~N}$ & $\mathrm{~N}$ & $\mathrm{~N}$ & $\mathrm{~N}$ & $\mathrm{~N}$ & $\mathrm{~N}$ & $\mathrm{~N}$ & $\mathrm{~N}$ & $\mathrm{~N}$ & $\mathrm{Y}$ & $\mathrm{N}$ & $\mathrm{N}$ & $\mathrm{N}$ & $\mathrm{N}$ & $\mathrm{N}$ & $\mathrm{N}$ \\
\hline \multirow{3}{*}{$\mathrm{C}$} & N5 $\rightarrow$ & Quantitative Indexes & a & $\mathrm{b}$ & $\mathrm{c}$ & d & e & $\mathrm{f}$ & $\mathrm{g}$ & $\mathrm{h}$ & $\mathrm{i}$ & j & $\mathrm{k}$ & 1 & $\mathrm{~m}$ & $\mathrm{n}$ & o & $\mathrm{p}$ & $q$ & $\mathrm{r}$ & $\mathrm{s}$ & $\mathrm{t}$ & $\mathrm{u}$ \\
\hline & N6 $\rightarrow$ & Partial DFA Indexes & \multicolumn{2}{|c|}{-} & $\mathrm{A}$ & $\mathrm{B}$ & $\mathrm{C}$ & $\mathrm{D}$ & E & $\mathrm{F}$ & G & $\mathrm{H}$ & $\mathrm{I}$ & $\mathrm{J}$ & $\mathrm{K}$ & $\mathrm{L}$ & $\mathrm{M}$ & $\mathrm{N}$ & $\mathrm{O}$ & $\mathbf{P}$ & Q & $\mathrm{R}$ & $\mathrm{S}$ \\
\hline & N7 $\rightarrow$ & Global DFA Indexes & \multicolumn{2}{|c|}{ AA } & B & & \multicolumn{2}{|c|}{$\mathrm{CC}$} & \multicolumn{7}{|c|}{$\mathrm{DD}$} & \multicolumn{7}{|c|}{$\mathrm{EE}$} & FF \\
\hline
\end{tabular}

FIGURE 4 - DFA evaluation matrix (Source: author, 2016).

$$
\begin{aligned}
& \text { Total }=\text { count } Y \\
& \text { Total }=\text { count } N \times \text { PFMax }+ \text { count } Y \times \text { PFMin }
\end{aligned}
$$

Levels N6 and N7 group level 5's numerical responses, generating partial and general indices of DFA that will be used to track design maturity evolution over the PDP. N6 relates to the specific DFMA guidelines presented in N2, and N7 groups the guidelines presented in N1. This is done through equations 3, 4, 5, 6 and 7. Equation 11 shows how much, in percentage, the evaluated components comply with the DFA guidelines. It is used in N6 for the indices from A to $\mathrm{D}$, and its best score is $100 \%$.

$$
(A \text { to } D) \text { Indexes }=\frac{\sum Y E S}{\sum Y E S+\sum N O} * 100 \%
$$


Equation 12 is applied for the indices from $\mathrm{E}$ to $\mathrm{S}$ and shows a relationship between the penalties applied to the project in N5 and the theoretical minimum number of parts, which is the quantitative index $b$, with the intent to compare not only the evolution within the same project, but also to others, since the theoretical minimum number is a standard used to measure project efficiency in terms of DFMA. Its best score is zero, which means that no penalty was applied.

$$
(\text { E to } S) \text { Indexes }=\frac{\text { Total }}{b}
$$

In N7, AA is obtained from Equation 13, presented in the Lucas method to calculate the efficiency of the assembly design, with the best score of $100 \%$.

$$
(A A) \text { Index }=\frac{b}{a}
$$

$\mathrm{BB}$ and $\mathrm{CC}$ follow Equation 14, which is an average of two partial directives. BB is called the Bill of Material (BOM) cost and needs the product's BOM to be composed, since it works on a comparative basis between the components. It is linked to the partial guidelines 3 and 4, analysis of standard components and analysis of project cost impact. The lower this index, the more disorganized components and/or with higher cost impact exist.

$\mathrm{CC}$ is a relative assembly analysis from the quality point of view by the Poka Yoke concept, which aims to ensure that the product assembly is error proof and is linked to guidelines 5 and 6 , the possibility of mounting the wrong component and the possibility of assembling the component in the wrong way, already presented in Figure 12. The lower this index, the less this criterion is met by the project.

$$
(B B \text { to } C C) \text { Indexes }=\frac{1}{2}(A+B) \text { or } \frac{1}{2}(C+D)
$$

DD and EE are related to Equation 15, which is the sum of the penalties within the general design guidelines 4 and 5, handling and joining and union. FF is equal to $\mathrm{T}$, because it is a 
design guideline chosen to be individually measured by its control complexity in the manufacturing processes. The lower this index, the more the project meets the criteria.

$$
\left(D D \text { to EE)Indexes }=\sum_{i=E}^{k} i \text { or } \sum_{i=L}^{R} i\right.
$$

The second stage of the study involved the DFM analysis, through the proposed DFM matrix based on the methodology of Lucas (1993), as illustrated in Figure 5. The component manufacturing analysis aims to identify indices of manufacturability to help measure the design evolution in terms of form changes or manufacturing processes. The DFM indices, such as the DFA, are also obtained by means of three partial and one general guideline, the partial ones being presented as: Relative manufacturing costs (Rc), which is associated with the analyzed component's design complexity. This guideline generates the partial index $\mathrm{T}$, which is calculated using Equation 3; Processing costs (Pc), which is associated with how close the component is to its final form in a single pass. This generates the partial index $U$, which is obtained from the table in Annex G; and Material Costs (Mc), which relativizes each component's manufacturing by standard cost-per-volume values and losses that are associated with the material and the chosen manufacturing process. This guideline generates the partial index $\mathrm{V}$, which is calculated using Equation 4.

The three combined partial guidelines result in the general guideline called General Manufacturing Costs (Mi), which is calculated using Equation 2 to obtain the general GG index. The indices T, U, V and GG are obtained from the summation of the indices referring to the manufacturing process of each assembly or subassembly (SB), as shown in equations 16,17 , 18 and 19.

$$
\begin{aligned}
& T \text { Index }=\sum_{i=A}^{A n} i \\
& U \text { Index }=\sum_{i=B}^{B n} i \\
& V \text { Index }=\sum_{i=C}^{C n} i \\
& G G \text { Index }=\sum_{i=D}^{D n} i
\end{aligned}
$$


Equation 20 shows the logic to find the value of $\mathrm{A}$, which is obtained by summing the results for each manufacturing stage from the respective subset (SB), and must be followed by the other items B, C, D, An, Bn, Cn and Dn.

$$
A=\sum_{i=A}^{A n} i
$$

\begin{tabular}{|c|c|c|c|c|c|c|c|c|c|c|c|c|}
\hline \multicolumn{13}{|c|}{ DFM MATRIX } \\
\hline & $\begin{array}{c}\text { Shape } \\
\text { complexity - Cf }\end{array}$ & Qty & Re & $\mathrm{Cc}$ & Cmp & $\begin{array}{c}\mathrm{Cs} \\
(\mathrm{Ct} \text { ou } \mathrm{Cf})\end{array}$ & Pc & Mc & $\mathrm{V}$ & Cmt & Wc & Mi \\
\hline SB 1 & & & $\mathbf{A}$ & & & & B & $\mathrm{C}$ & & & & D \\
\hline \multicolumn{13}{|l|}{ Component A - Manufacturing step 1} \\
\hline \multicolumn{13}{|l|}{ Component A - Manufacturing step n } \\
\hline \multicolumn{13}{|l|}{ Component $\mathrm{n}$ - Manufacturing step 1} \\
\hline \multicolumn{13}{|l|}{ Componente $\mathrm{n}$ - Manufacturing step $\mathrm{n}$} \\
\hline SB n & & & An & & & & Bn & Cn & & & & Dn \\
\hline \multicolumn{13}{|l|}{ Component B - Manufacturing step 1} \\
\hline \multicolumn{13}{|l|}{ Component B - Manufacturing step n } \\
\hline \multicolumn{13}{|l|}{ Component $\mathrm{n}$ - Manufacturing step 1} \\
\hline \multicolumn{13}{|l|}{ Component $\mathrm{n}$ - Manufacturing step $\mathrm{n}$} \\
\hline DFM globla and partial indexes & & & $\mathbf{T}$ & & & & $\mathbf{U}$ & $\mathbf{V}$ & & & & GG \\
\hline
\end{tabular}

FIGURE 5 - DFM evaluation matrix (Source: adapted from Lucas, 1993).

All those indices for DFA and DFM must be transcribed into the matrix from Figure 5, which numerically summarizes the project's analyses according to the DFMA criteria and enables follow-up weak and strong project points analysis as well as the project's evolution. Figure 06 presents the results of this preliminary model study.

Field $\mathrm{A}$ is the table header, where the maturity stages and their general criteria $(\mathrm{AA}, \mathrm{BB}, \mathrm{CC}$, DD, DD, FF, GG) obtained from the DFA evaluation matrix, Figure 03, applied in the study, are presented. This field also presents the reference values for each general criterion. When there is no reference value for some criterion, Bt2 will appear, which means that the last evaluation stage should have a better value than the previous one.

Field B presents a list of the partial guidelines and their respective indices, each considering the last evaluation step, in this case step MRL4. The scores are the indices resulting from the DFA analysis, brought from the DFA evaluation matrix, Figure 4, applied in the study.

Field $\mathrm{C}$ connects the partial to the general guidelines or criteria, already presented in the study. 


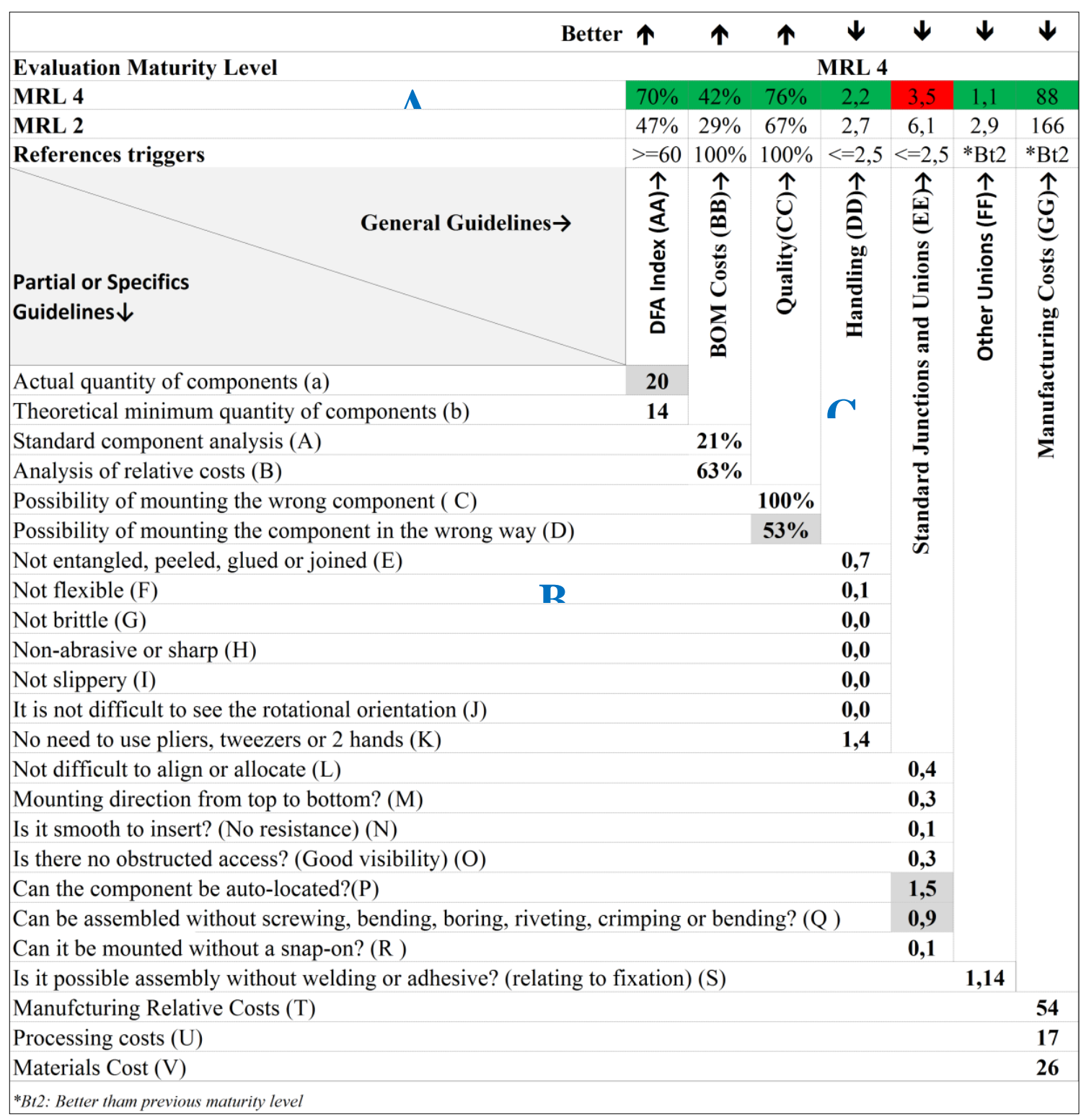

FIGURE 6 - Maturity evolution matrix (Source: author, 2016).

Based on the model's results, summarized in Figure 6, it is possible verify that the proposal allowed to follow the project's evolution based on the general and partial guidelines obtained through the use and adaptation of the DFMA techniques in the DFA, DFM and DFMA matrices, throughout the project's maturity stages defined as MRL2, MRL3 and MRL4 on the table header. It is notably easy to identify the points of product improvement by looking at the 
guideline indices presented in fields B and C. Those product improvement points were key elements that guided the changes in the product's concept.

The changes in product concept are reflected in the increasing of the general and partial guideline values. The main impact was the product cost reduction by $25 \%$ and project investiment reduction by $20 \%$ evaluated by the project team. The earlier manufacturing and assembly project noticeably allowed a more reliable debugging of the product, yielding a reduction in the execution time.

The increase from $47 \%$ to $70 \%$ in the DFA general guideline in the MRL2 to MRL4 maturity stages is an example of a result obtained from design reduction and simplification, which, in addition to reducing the transformation and investment costs, reduces assembly risks, replacing unknown or complex technologies for simpler ones, serving the same functional requirements. The second important generated document, which guides decisions to finish SAT maturity level, is the SAT check list adherence. This check list is composed by some important criteria and topics to be evaluated. $100 \%$ compliance is ideal.

The last important document is the Risk Matrix, which must be filled following previously presented instructions.

\section{EVALUATION}

The model evaluation aims to identify its potential use in project environments during preliminary stages of development, as well as improvement opportunities.

The proposal follows the experiments already conducted by Inthamoussu, 2015, and will take place in two stages: a workshop for the presentation and development of an experiment with a project team composed of 16 people working in research and development at a multinational metal mechanic company, and an evaluation questionnaire for the professionals who participated in the case study, in order to reflect on the potential results with the system's application. 


\section{CONCLUSIONS}

The objective of this work was to propose a model for the integration of the knowledge areas of design and manufacturing, in the development stage of product technologies using DFMA, MRL and TRL.

The use of 3 matrices results in a change of product design and manufacturing process with a product cost reduction of $20 \%$ and project investment reduction of $25 \%$. The main elements modified in the project, results in:

- $33 \%$ reduction in the number of parts, which is reflected in the increase of the DFA index from 47 to $70 \%$;

- Change in the concepts of components' union, mainly eliminating the need to use adhesive, which is reflected in the increase of the index referring to the DFA guideline, other unions, which was 2.9 at the level MRL2 and was reduced to 1.1 in MRL4;

- Change in component manufacturing concepts, represented by the improvement in the overall manufacturing costs guideline, which was 166 at the MRL 2 level and was reduced to 88 at MRL4.

- The main impact was caused by changes in concepts that require manufacturing processes with high investment levels, such as Grinders for finishes and Machining Centers for complex shapes, moving to simpler processes with lower levels of investment required, such as tools stamping and machining with conventional lathes.

The model application was validated through the systematic presented in the form of a table with tasks and tools to be applied in research and development projects, along with the evolution of its maturity divided into three macro phases and four levels of maturity. The answers for the questions related to the selected criteria prove the effectiveness of the results through the three indices: The first one refers to the evaluation of the model as a work tool here $95 \%$ of the answers affirm that it is, indeed, a work tool. Regarding whether the model contributed to the company where the workshop was applied, $90 \%$ of the answers said they meet the criteria. The index that evaluates the proposal as a reference model obtained $92 \%$ of positive answers. 


\section{REFERENCES}

ARAÚJO, C.S., MOCKZYDLOWER, D. Uma abordagem para estruturação integrada de projetos de inovação tecnológica pré-competitiva. Junho-Julho 2017. Mundopm.com.br. EMBRAER- Empresa Brasileira de Aeronáutica, pgs 42- 47, Brasil.

BOOTHROYD, Geoffrey; DEWURST, Peter; KNIGHT, Wiston A, Design for Manufacturing and Assembly Third Edition .CRC Press, New York, 2011.

COOPER, R. G. Third-Generation New Product Processes.Journal of Product Innovation Management, v.11, p.314,1994. http://dx.doi.org/10.1016/0737-6782(94)90115-5.

EHRS, Mikael, Is the Automotive Industry Using Design-for-Assembly Anymore?, Ph.D. dissertation, Industrial Management 27- Acta Wasaensia 273- University of Vaasa .Vaasa, Finland, 2012.

ESQUILANDER, Stephan. Design for Automatic Assembly: A Method for product design : DFA2. Doctoral Thesis, Department of Production Engineering- Royal Institute of Technology, Stockholm, Sweden, 2001.

HADDAD, H. G., BACKAR, S.H., EL-KADEEM, R.A.,DARDIRY, M.A. Dynamic View of Product Development Process. First International Conference on Innovative Engineering Systems, 10.1109/ICIES.2012.6530872, Alexandria, Egito, 2012.

INTHAMOUSSU, E.M.R. Sistemática para a integração do planejamento do produto com o planejamento do projeto: Enfoque no desenvolvimento de tecnologias para eletrodomésticos. 2015. Dissertação (Mestrado) Programa de Pós-graduação em Engenharia Mecânica, Engenharia Mecânica, Universidade Federal de Santa Catarina, Florianópolis.

KARNIEL, A., REICH, Y. Formalizing a Workflow-Net Implementation of Design-Structure-Matrix-Based Process Planning for New Product Development. IEEE transactions on systems, man ,and cybernetics - part A: systems and humans, VOL. 47, No. 3, , 0.1109/TSMCA.2010.2091954, Tel Aviv, Israel, 2011.

LUCAS ENGINEERING SYSTEMS LTD, Design for Manufacture and assembly Practitioners Manual. Version 10, University of Hull, England, 1993.

MANKINS, J.C. Technology readiness assessments: A retrospective, Acta Astronautica 65 1216-1223, 2009.

MARXT, C. HACKLIN, F. ROTHLISBERGER, C. e SCHAFFNER, T. End-to-End Innovation: Extending the Stage-Gate Model into a Sustainable Collaboration Framework. In: M. Xie, T. S. Durrani, H. K. Chang (Eds.), Proceedings of the IEEE International Engineering Management Conference, Vol. 3, pp. 963-967, Singapore, 2004.

OSD Manufacturing Technology Program. Manufacturing Readiness Level (MRL) Deskbook. Washington DC, 2011

STIENSTRA, David, 2016, Introduction to Design for (Cost Effective) Assembly and Manufacturing, Accessed: 13.04.2016 [ online ]. Available: https://www.rose-hulman.edu/ stienstr/ME470/DFA.ppt. 